\title{
Native and Exotic Insect Borers Are Important Crop Pests in the U.S. 1
}

Daniel L. Frank and Russell F. Mizell, $I I^{2}$

\section{Introduction}

Insect borers attack a wide range of agricultural, ornamental, landscape, and forest trees. Concerns are growing throughout the United States for the economic and aesthetic damages caused by these insects. Woodboring insects are particularly problematic because injury is not generally noticed until extensive damage has occurred, which makes effective management of these pests difficult. Relatively little is known about the general biology and behavior of many species of insect borers. In addition, comparatively little research has been conducted on the relationships between woodborers and host plants.

While a few very destructive exotic species (Table 1) are receiving a great deal of national attention, hundreds of native woodboring insects that are responsible for millions of dollars of damage and cost of controls each year are receiving little attention (Table 2). This can be partially attributed to the cryptic nature of most insect borer pests. Infestations are usually overlooked until sizeable damage has occurred. Once damage has been assessed, chemical or mechanical means of control are most often used to manage borer problems. As the amount of damage from these insects increases, so must our knowledge of the ecological interactions between insect borers and their hosts. Effective control can usually only be achieved if management occurs before significant damage has taken place.

\section{Diversity}

Woodborers are a diverse and important group. The diversity of these insects spans four taxonomic orders, and over 20 families. In order of importance, Coleoptera, Lepidoptera, Hymenoptera, and Diptera are the insect orders containing most borers. Important families include: the metallic woodboring beetles, longhorned beetles, bark and ambrosia beetles (Coleoptera), and the clearwing moths (Lepidoptera) to name only a few. The sheer taxomonic, ecological and morphological diversity of woodboring insects is astounding. Thousands of North American species have been named, and a wide variety of host plants are susceptible to their attack.

Buprestidae. Metallic wood borers, or flat-headed borers, get their name from the distinctive metallic colors shown by adults (Figure 1). Adult

1. This document is ENY-730 (IN640), one of a series of the Entomology and Nematology Department, Florida Cooperative Extension Service, Institute of Food and Agricultural Sciences, University of Florida. First published: April 2006. Please visit the EDIS Website at http://edis.ifas.ufl.edu.

2. Daniel L. Frank, graduate student, and Russell F. Mizell, III, professor, Entomology and Nematology Department, North Florida Research and Education Center, Institute of Food and Agricultural Sciences, University of Florida, Quincy, FL.

The Institute of Food and Agricultural Sciences (IFAS) is an Equal Opportunity Institution authorized to provide research, educational information and other services only to individuals and institutions that function with non-discrimination with respect to race, creed, color, religion, age, disability, sex, sexual orientation, marital status, national origin, political opinions or affiliations. U.S. Department of Agriculture, Cooperative Extension Service, University of Florida, IFAS, Florida A. \& M. University Cooperative Extension Program, and Boards of County Commissioners Cooperating. Larry Arrington, Dean 
beetles have a flattened appearance and are generally hard-bodied with short antennae. Larvae are legless with flattened body segments just behind the head. Important species within this family include the native bronze birch borer, Agrilus anxius Gory, and a new exotic species in the mid western U.S., the emerald ash borer, Agrilus planipennis Fairmaire.

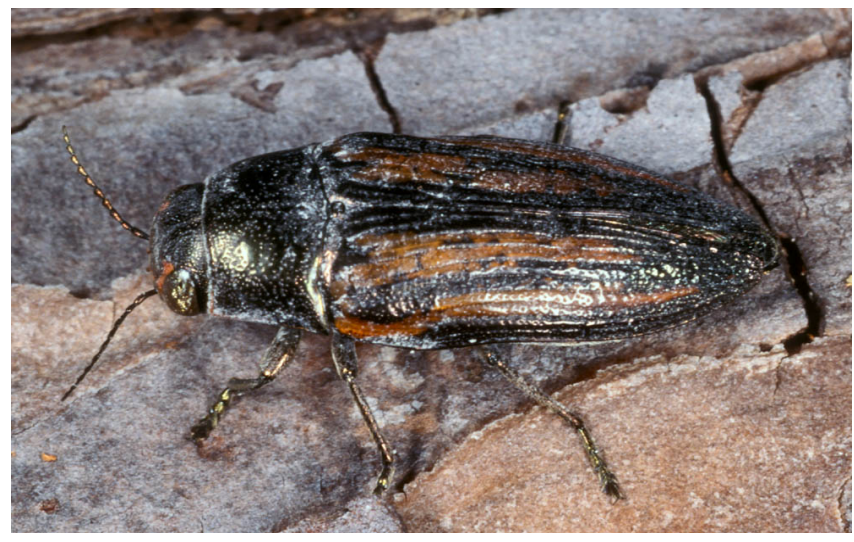

Figure 1. Buprestidae adult, Buprestis lineate.

Cerambycidae. Longhorned beetles, or round-headed borers, are a large and diverse family of insect borers. Adult beetles get their name from the characteristically long antennae found on most species (Figure 2). Larvae generally have three pairs of small thoracic legs. Important species within this family include the redheaded ash borer, Neoclytus acuminatus (Fabricius), the twig girdlers, Oncideres species, and the exotic Asian longhorned beetle, Anoplophora galbripennis (Motschulsky).

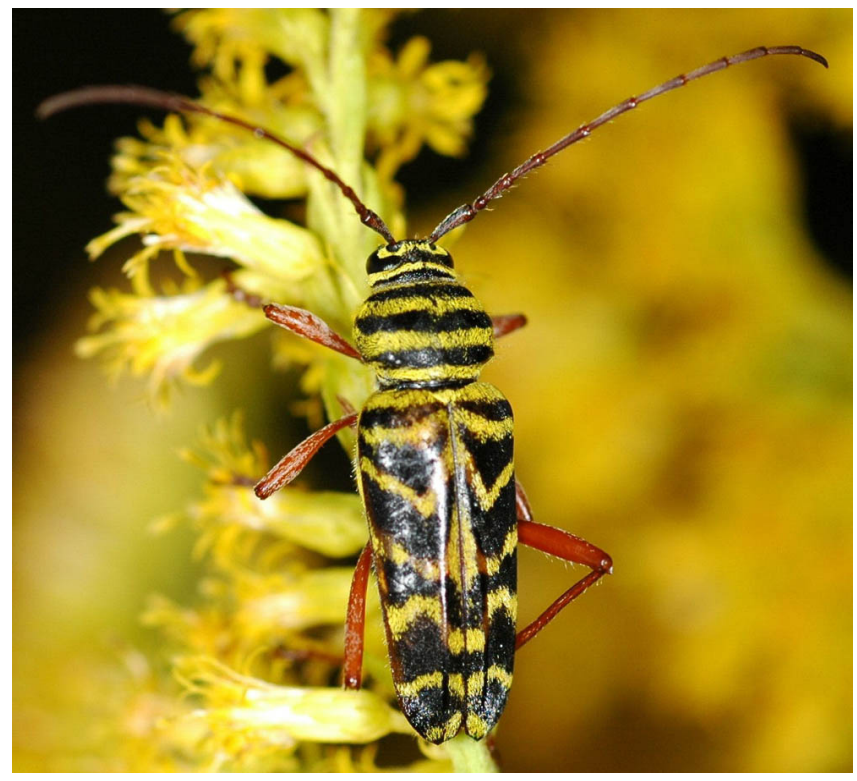

Figure 2. Cerambycidae adult, Megacyllene robiniae.
Scolytidae. The family Scolytidae can generally be broken down into two groups, the bark beetles and ambrosia beetles. Members of both groups are small reddish-brown to black insects (Figure 3). Larvae are legless and very small. Bark beetles are important forest pests, while ambrosia beetles are predominantly nursery and landscape pests. Some scolytids transmit fungal diseases to plants. For example, the European elm bark beetle, Scolytus multistriatus (Marsham), is the carrier of the fungal pathogen that causes Dutch elm disease. Other important species include the native southern pine beetle, Dendroctonus frontalis Zimmermann, the shothole borer, Scolytus rugulosus (Mueller), and the exotic granulate ambrosia beetle, Xylosandrus crassiusculus (Motschulsky).
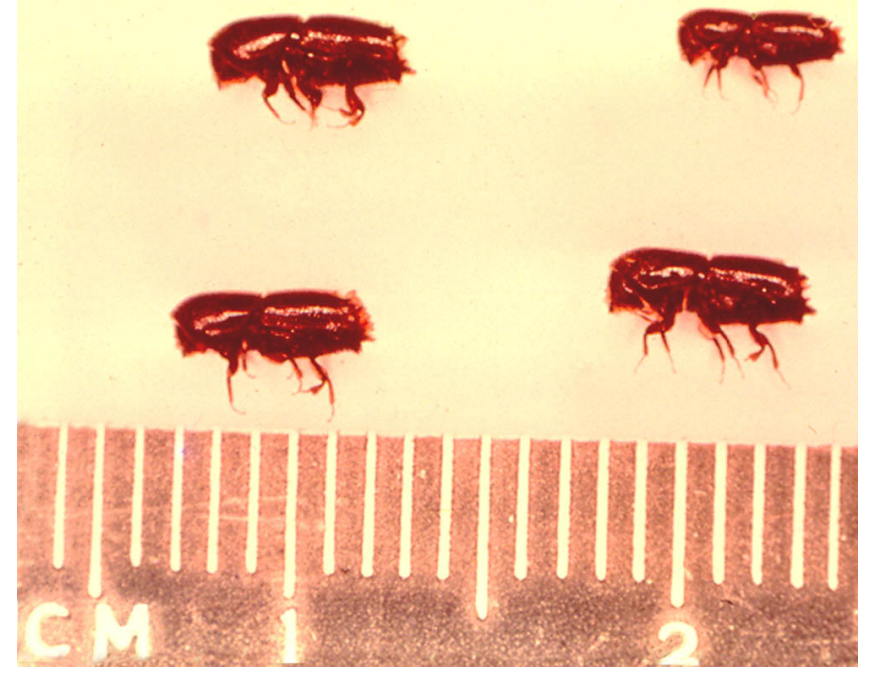

Figure 3. Scolytidae adult, Ips. spp.

Sesiidae. Clearwing moths are easily recognized by the transparent areas that make up the wings (Figure 4). Most adult moths are day fliers and wasp-like in appearance. Larvae have three pairs of thoracic legs in addition to abdominal pro-legs. Important species include the peach tree borer, Synanthedon exitiosa (Say), lesser peach tree borer, Synanthedon pictipes (Grote and Robinson), and the dogwood borer, Synanthedon scitula (Harris).

\section{Damage}

Woodborers can be broken down into two general categories based on the condition of the larval host plant at the time of colonization. These categories include primary invaders, which attack apparently healthy trees, and secondary invaders, 


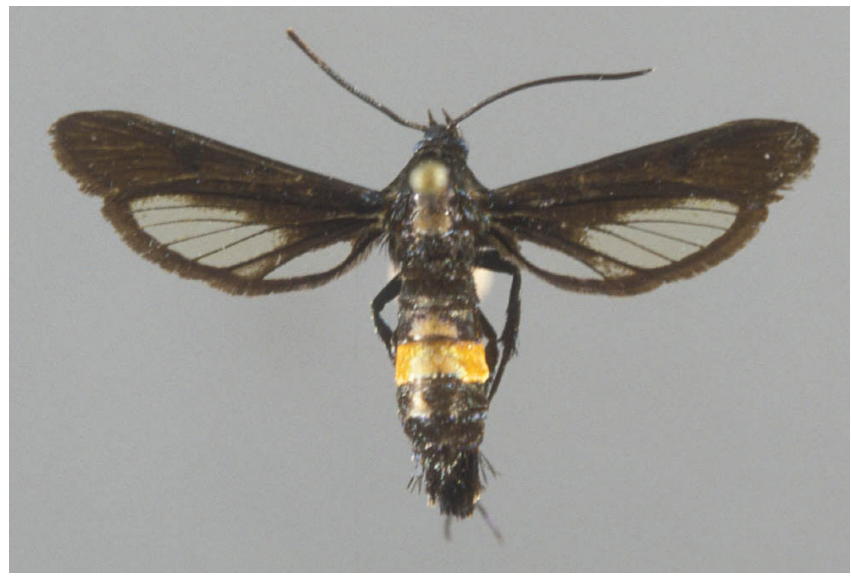

Figure 4. The peachtree borer, Synnanthedon exitiosa.

which attack stressed, dying or dead trees. Many woodboring insects feed on subcortical tissues, which consist primarily of the inner bark, phloem, and immature xylem of host trees (Figure 5). In addition, the bark, sapwood, heartwood, and pith may also be fed upon to a lesser extent. Fungal hyphae in the plant and cellulose-digesting enzymes in the insect may also be utilized to assist in nutrient assimilation of nutrient-poor host tissue.

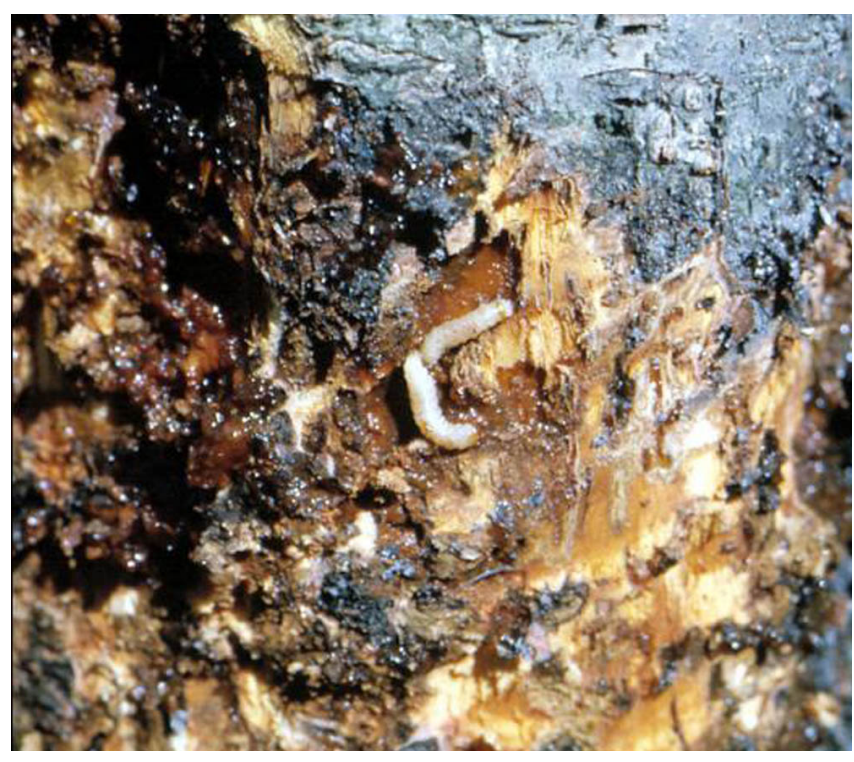

Figure 5. Damage of the pechtree borer larvae, S. exitiosa.

The larvae of insect borers cause extensive galleries, or tunnels, that can run throughout the vascular tissue of host trees. These galleries grow larger as the larvae mature. Woodborer damage can consist of the girdling and destruction of vascular plant tissue, weakening of trunks and branches as well as the creation of wounds that allow entry of diseases. Many adult borers will also feed on foliage, needles, stems and shoots, floral resources, or seeping sap of host trees creating further damage.

It is often difficult to detect woodborers in newly infested trees. Damage is usually not seen until after at least a year, when exit holes created by adults are visible on the branches and trunks of host trees. Holes are generally round, oval or semicircular and are found in a random pattern on the plant. Gum will often form as the sap exudes and hardens over the entrance to the gallery while in other plant species sawdust-like frass is associated with the entrance or exit holes. Noticeable, also, may be vertically split bark created by larval feeding galleries. Over time, foliage may wilt and the tree canopy may become increasingly sparse as branches die. Epicormic shoots, adventitious branches on the lower trunk, may also arise on the trunk of trees at the margin of living and dead tissue. Under intense pressure, the tree will eventually die.

Economic damage associated with insect borers remains an important issue of concern to many growers throughout the country. The damage caused by these pests can include drastic decreases in the number of fruit and nut bearing branches in orchards and groves, stunted and deformed trees within hardwood plantations, and aesthetic damage to ornamental and landscape trees and shrubs. In some cases, these pests have destroyed entire forests, urban landscapes, plantations, and orchards. Current research involving these insects has focused predominantly on forest and exotic woodboring species. Comparatively little research is conducted on woodboring pests that affect fruit and nut crops, which are multi-billion dollar industries. Rising costs associated with preventing insect borer related problems, combined with cheaper imports, have threatened the production and value of many U.S. fruit and nut crops.

Unfortunately, the cryptic habits of insect borers have hindered efforts to document their activity and develop appropriate management methods. Much of the information on insect borers is widely scattered and found in older, less accessible literature. In addition, research on insect borers is commonly restricted to very few pest species. 


\section{Plant Defenses and Borer Infestations}

Healthy, vigorously-growing trees often have very efficient mechanisms to prevent woodborer infestations. For instance, proper sap flow can be a good deterrent to many borer pests by preventing them from tunneling into the vascular tissue. Wound induced callus tissue, or periderm, can also act as a mechanism for borer resistance. Callus tissue is produced by a plant as developing larvae tunnel through the vascular tissue. The tissue encapsulates larvae and prevents borer development by starving or crushing them. In addition, the high moisture content of bark and secondary plant chemicals such as resins may also play a role in host plant resistance.

Stressed trees are generally thought to be more susceptible to woodborer attack because their defense mechanisms are weakened. Research has shown that resistance to larval borers vanishes as callus formation slows. If the borer larvae move faster through the vascular tissue than callus formation, then the larvae may live to complete development. Strong defense responses are dependant on proper carbon translocation from the tree canopy to the trunk. If severe drought or defoliation stress occurs, it can limit the amount of carbon translocation and have detrimental effects on plant defense responses.

Although tree stress caused by factors such as drought, poor soil quality, or reduced light can reduce or weaken plant responses to insect borers, evidence has shown that even unstressed host trees can be susceptible to certain woodboring insects. Stress may have no effect on resistance if trees are inherently susceptible to a particular insect borer species. Tree species with no co-evolutionary history with an associated insect borer can be extremely susceptible to attack, as no host resistance genes exist. In some cases, cultural practices such as pruning, fertilizer, soil compaction and improper irrigation regimes increase susceptibility by making trees more attractive to borers.

Despite our current knowledge of woodborer behavior, it is often difficult to identify the initial condition of larval host plants because researchers rarely have the opportunity to assess plant conditions prior to discovering that the plant has come under attack. The diversity in the condition of larval host plants at the time of colonization has led Hanks (1999) to categorize woodboring insects according to specific aggression levels. These categories include species that attack healthy hosts, weakened hosts, stressed hosts, or dead hosts.

Unfortunately, general patterns between borer species and hosts remain unresolved, the function of resistance genes is unclear, and the mechanisms by which one borer species succeeds and another fails requires further investigation. In addition, many species initially considered to attack host trees in any state of health have been found to restrict their attacks to hosts of a particular condition. Only with a greater understanding of the complexities of the interactions between borer and host can efficient control be accomplished.

\section{Exotic Borer Pests}

As our economy and current trade practices become increasingly global, so does the potential for more damage by these insects. By conservative estimates, over 2,000 exotic insects are now in the U.S., with over 400 of them feeding on woody plants. Almost every tree genus in the U.S. has at least one exotic insect, with some having more than 40 . Currently, only five of the 400 exotic woody plant pests are now regulated by federal quarantine. These include the Japanese beetle, pine shoot beetle, Asian longhorned beetle, emerald ash borer, and gypsy moth. Unfortunately, despite quarantine efforts, damage from these pests and other insect borers remains high. Exotic insect borers, along with native North American borers, are changing the landscape across the country.

Major sources for exotic borer introductions include pallets, spools, crating, and dunnage that enter the country daily. To a lesser extent, the transportation of seeds and plant cuttings, in addition to the nursery trade, have also been important pathways. Currently, over 10 million containers used in transporting these commodities enter the U.S. each year and this is expected to quadruple by 2020 . Potential for introduction arises because these containers are typically not opened until they reach their final destinations. This problem is further compounded by the fact that only 2-4 percent of these containers entering the country are ever inspected. 
Since 1992, fourteen new exotic woodborers have become established in the U.S. These insects first appeared in 12 states located throughout the country, and since 2004 have spread to 37 states. Despite preventive measures, these insects have continued to enter the country and cause damage. These pests only add to management problems related to native woodborers that continue to cause serious losses in a variety of crops.

\section{Management}

Current insect borer management practices involve several tactics and strategies that are used collectively as an integrated approach to pest management (IPM). Insect borer IPM practices are multifold and involve several techniques that may be used depending on the type of borer pest and the host plant. Although these management practices can be effective when used alone, collectively they are much more efficient in combating many borer species.

Monitoring. The first step in managing any pest species begins with a proper monitoring program. Efficient monitoring tools are essential for accurate and cost effective management programs. A number of methods have been developed to monitor woodboring pest species. Common monitoring tools include sticky traps, funnel traps, pyramid traps, and circle traps. Traps capture borers by exploiting their behavioral and physiological responses to color, trap placement and design, and pheromones. Pheromone lures are often the best method for attracting woodborer species because they are species and sex specific. However, research involving these lures has been restricted to only a few major woodboring pest species.

Mechanical Control. Removing and destroying infested, dying, or dead plants and plant parts can often be the best defense for current and future infestations. If infestation numbers are low, direct removal of larvae from trees using a knife or metal hook can be a potential option for control.

Chemical Control. Chemical control is the most common preventative measure for insect borer infestations. However, very few effective pesticides have been registered for use against woodborers, and many of the older chemicals have been discontinued.
Often only newly transplanted trees and shrubs, or high value ornamental and landscape trees, justify the cost of using chemical management. Most insecticides registered for woodborer control are residual insecticides, which are applied as sprays to trunks and branches of host trees. These insecticides work by killing adult and early larval stages that tunnel through the treated bark layer. Another chemical control method is trunk injection, which delivers insecticide into the cambium and phloem tissues where insect borers feed. However, research has shown that the damage caused by inserting the injection devices into trunks can significantly harm the host tree, and in some cases have even attracted pest species to the treated area.

Biological Control. Biological control is currently a little-used management practice for insect borers. Natural enemies have often been overlooked as a suitable control method because very little is known about these organisms in relation to insect borers. In addition, borer damage tends to occur before most natural enemies can effectively suppress these pests. However, entomopathogenic nematodes have been used with some success. Continuing research involving these organisms has shown promise for future borer management.

Prevention. Borer populations are often limited by environmental conditions and food (i.e., host plants in the proper condition). Environmental factors that cause periodic outbreaks, such as adverse weather conditions, are often uncontrollable. However, recognizing tree, stand, and landscape factors that predispose a plant to woodborer infestations is the first step in a prevention program.

The vast majority of woodboring insects are considered secondary invaders. Good horticultural and/or silvicultural practices that keep trees healthy are often the best defense against these pests. Appropriate care of trees and shrubs can discourage many borer pests, and can even help infested plants survive. Any activity that can reduce tree stress can potentially be an effective measure for control. These activities can include: avoiding injury to trunks and branches, proper site selection of host plants, selection of well-adapted host species to a given area, proper watering and fertilization regimes, and proper 
care of injured plants. Other activities such as trunk wrapping to prevent mechanical injury have shown mixed results, and in some cases have actually promoted infestation. For instance, damage from outbreaks of southern pine beetle, a severe pest of conifers in the southeast, can be minimized if proper silvicultural practices are conducted. Research and experience have shown that pine forests that are either overcrowded, overmature, or located on poorly drained bottomland soils are more likely to suffer from southern pine beetle infestations.

\section{Conclusion}

Relative to other better-known insect pests, very few tools are available for management of woodborers. Many suppression tactics used for managing insect borers can be time consuming, expensive, or environmentally unfriendly. In many cases there is no guarantee that these tactics will be effective against woodborer attack. Unfortunately, our knowledge of the basic biology of many insect borers is limited. In addition, monitoring and sampling of many borer pests is inefficient, or simply not conducted for preventative management to take place. Current control tactics are useful to limit the damage that occurs from insect borer infestations. However, continued research and a greater understanding of the biology of these pests is vital before effective management can occur.

Preventative measures such as proper horticultural practices and removal of infested, dying, or dead plants and plant parts are a simple but effective step for controlling many borer pests. Although chemical methods of control can be expensive and environmentally unfriendly, proper steps can be taken to reduce their costs and damage to the environment. Proper timing of chemical treatments to match the phenology of insect borers and their hosts as well as minimizing the amount of drift that occurs during spraying are both key factors that should be considered before insecticide application occurs. Further research involving reduced-risk insecticides and biological control must also be investigated as a means for reducing environmental concern and management costs. Additionally, simple actions such as restricting firewood transport across potential infestation sites, or identifying and reporting borer species of concern, can be successful to reduce the spread and severity of insect borer damage.

Once the mechanisms accounting for insect borer and host responses are known, their responses will become more predictable allowing current management strategies to be refined and integrated to enhance their effectiveness and acceptance in future management programs. Currently, very little research has been done on many important insect borers and their relationships with their hosts. Without further research and information, future infestations and damage will occur and may change our landscape forever.

\section{Further Reading}

Allison, J., J. Borden and S. Seybold. A review of the chemical ecology of the Cerambycidae (Coleoptera). Chemoecology 14:123-150.

Brown, L. N. and R. F. Mizell, III. 1993. The clearwing borers of Florida. Trop. Lepid. 4. Supplement 4. $21 \mathrm{pp}$.

Drooz, A. T. 1985. Insects of eastern forests. USDA For. Serv. Misc. Pub. 1426. Washington, D.C.

Hanks, L. M. 1999. Influence of the larval host plant on reproductive strategies of cerambycid beetles. Annu. Rev. Entomol. 44: 483-505.

Solomon, J. 1995. Guide to insect borers in north American broadleaf trees and shrubs. USDA-FS Agric. Handbook AH-706. 735 pp. 
Native and Exotic Insect Borers Are Important Crop Pests in the U.S.

Table 1. Some exotic woodborers of economic importance.

\begin{tabular}{||l|l|l||}
\hline \hline \multicolumn{1}{|c||}{ Family } & \multicolumn{1}{c||}{ Species } & \multicolumn{1}{c||}{ Host or Crop Infested } \\
\hline Buprestidae & Agrilus planipennis & Ash \\
\hline Cerambycidae & Anoplura glabripennis & Hardwoods \\
\hline Scolytidae & Xylosandrus crassiusculus & Hardwoods \\
\cline { 2 - 4 } & X. mutilatus & Hardwoods \\
\cline { 2 - 4 } & Tomicus piniperda & Conifers \\
\hline \hline
\end{tabular}

Table 2. Some native woodborers of economic importance.

\begin{tabular}{|c|c|c|}
\hline Family & Species & Host or Crop Infested \\
\hline \multirow[t]{6}{*}{ Buprestidae } & Agrilus anxius & Birch \\
\hline & Agrilus politus & Willow, Maple \\
\hline & Agrilus sayi & Bayberry, Sweetfern \\
\hline & Agrilus vittaticolllis & $\begin{array}{l}\text { Apple, Pear, Cranberry, Serviceberry, } \\
\text { Hawthorn }\end{array}$ \\
\hline & Chrysobothris femorata & $\begin{array}{l}\text { Apple, Apricot, Beech, Boxelder, Cherry, } \\
\text { Chestnut, Currant, Elm, Hawthorn, Hackberry, } \\
\text { Hickory, Horsechestnut, Linden, Maple, } \\
\text { Mountain-ash, Oak, Pecan, Pear, Peach, } \\
\text { Persimmon, Plum, Poplar, Quince, Redbud, } \\
\text { Serviceberry, Sycamore, Walnut, Willow }\end{array}$ \\
\hline & Texania campestris & $\begin{array}{l}\text { Basswood, Beech, Maple, Oak, Sycamore, } \\
\text { Willow, Yellow-poplar }\end{array}$ \\
\hline
\end{tabular}


Native and Exotic Insect Borers Are Important Crop Pests in the U.S.

Table 2. Some native woodborers of economic importance.

\begin{tabular}{|c|c|c|}
\hline Family & Species & Host or Crop Infested \\
\hline \multirow[t]{9}{*}{ Cerambycidae } & Goes pulverulentus & $\begin{array}{l}\text { Beech, Elm, Nuttall, Willow, Black oak, } \\
\text { Cherrybark oak, Water oak, Sycamore }\end{array}$ \\
\hline & Goes tigrinus & Oak \\
\hline & Neoclytus acuminatus & $\begin{array}{l}\text { Ash, Hickory, Oak, Walnut, Birch, Beech, } \\
\text { Maple, Eastern hophornbeam, Dogwood, } \\
\text { Persimmon, Redbud, Holly, Hackberry, Black } \\
\text { locust, Honeylocust, Yellow-poplar, Chestnut, } \\
\text { Osage-orange, Sassafras, Lilac, } \\
\text { Mountain-mahogany, Pear, Cherry, Plum, } \\
\text { Peach, Apple, Elm, Basswood, Sweetgum }\end{array}$ \\
\hline & Neoptychodes trilineatus & $\begin{array}{l}\text { Fig, Alder, Mulberry, Willow, Netleaf } \\
\text { hackberry }\end{array}$ \\
\hline & Oberea ocellata & $\begin{array}{l}\text { Sumac, Apple, Peach, Plum, Pear, Currant, } \\
\text { Blackberry }\end{array}$ \\
\hline & Oberea tripunctata & $\begin{array}{l}\text { Dogwood, Viburnum, Elm, Sourwood, } \\
\text { Blueberry, Rhododendron, Azalea, Laurel, } \\
\text { Poplar, Willow, Mulberry }\end{array}$ \\
\hline & Oncideres cingulata & $\begin{array}{l}\text { Hickory, Pecan, Persimmon, Elm, Sourwood, } \\
\text { Basswood, Honeylocust, Dogwood, } \\
\text { Eucalyptus, Oak, Hackberry, Maple, Fruit } \\
\text { trees }\end{array}$ \\
\hline & Saperda calcarata & Poplar \\
\hline & Strophiona nitens & $\begin{array}{l}\text { Chestnut, Oak, Hickory, Walnut, Beech, } \\
\text { Maple }\end{array}$ \\
\hline \multirow[t]{6}{*}{ Scolytidae } & Corthylus columbianus & $\begin{array}{l}\text { Maple, Oak, Yellow-poplar, Beech, Boxelder, } \\
\text { Sycamore, Birch, Basswood, Chestnut, Elm }\end{array}$ \\
\hline & Dendroctonus frontalis & Pine \\
\hline & Dryocoetes betulae & Birch, Sweetgum, Wild cherry, Beech, Pear \\
\hline & Monarthrum fasciatum & $\begin{array}{l}\text { Oak, Maple, Birch, Chestnut, Sweetgum, } \\
\text { Blackgum, Poplar, Hickory, Mimosa, Apple, } \\
\text { Peach, Pine }\end{array}$ \\
\hline & Phloeotribus liminaris & $\begin{array}{l}\text { Peach, Cherry, Plum, Black cherry, Elm, } \\
\text { Mulberry, Mountain-ash }\end{array}$ \\
\hline & Pseudopityophthorus pruinosus & $\begin{array}{l}\text { Oak, American beech, Black cherry, } \\
\text { Chickasaw plum, Chestnut, Maple, Hickory, } \\
\text { Hornbeam, Hophornbeam }\end{array}$ \\
\hline
\end{tabular}

